\title{
Beyond dependency: the promise of Confucianism in Post-Westphalia International relations
}

Ricky Wai-kay Yue

\author{
Correspondence: \\ ricky_yue@yahoo.com \\ City University of Hong Kong, Tat \\ Chee Ave, Hong Kong
}

\begin{abstract}
The landscape of post-colonial development is marked by deepening dependency of the developing states on the core states consisted mainly of western developed countries. The continuous widening of the north-south divide is not surprising given that the discourse on international relations has been dominated by western ideologies of realism, liberalism and constructivism, resulting in an insufficient attempt to examine international relations from a non-Westphalian perspective. Through the implementation of the Washington Consensus, developing countries are being forced to follow the development model of liberal democracy designed by the West, for the benefit of the West. This paper attempts to investigate an alternative approach from a Chinese historical structural perspective. By highlighting the key tenets of Confucianism, this paper aims to contribute towards a non-Western international relations discourse that is based on moral values. Attempts by China to provide assistance to the "poor south" are marred by accusations of neo-colonialism. In order to fulfil its great power responsibility, China needs to incorporate these Confucian values into its Beijing Consensus so that the global south can abandon their dependency on the West and truly set the stage for south-south cooperation.
\end{abstract}

Keywords: Dependency; Confucianism; South-south cooperation; Beijing Consensus; China external relations; Bandung

\section{Introduction}

The concept of sovereign state emerged from Europe after the end of the Thirty Years' War and the Westphalian Peace in 1648. The key tenets of a post-Westphalian order are territorial integrity, mutual respect of each other's sovereignty, and the equality among states (Schmidt 2011). States become a unit of analysis in international relations. Yet, the boundaries of states have been breached with the rapid development of capitalism that drove European states to imperialism and ultimately colonialism (Lenin 1916 [1982]). After the Second World War, although colonialism has lost its appeal in shapes and forms, replaced it is a new wave of neo-colonialism based on a system of unequal exchange that leads to the underdeveloped peripheral countries continue to serve the rich core industrialised countries. Early dependency theorists asked why developing countries remained underdeveloped, and exploitation was among their common conclusions (Dos Santos 1971; Frank 1967; Amin 1974). Whilst dependency theory shares the same critical epistemological root as Marxism, it is nonetheless different in that Marxism examines exploitation from the micro-economic process of production, whereas dependency school

(c) 2015 Yue; licensee Springer. This is an Open Access article distributed under the terms of the Creative Commons Attribution License (http://creativecommons.org/licenses/by/4.0), which permits unrestricted use, distribution, and reproduction in any medium, provided the original work is properly credited. 
looks from a macro-economic perspective of the global exchange system. After the Second World War, the global economic order is structured under international organisations such as the World Bank and the International Monetary Fund (IMF), both legacies of the US directed Bretton Woods conference. Far from setting a level playing field for the underdeveloped countries, their policies forced the domestically weak countries to carry out liberal reforms such as privatisations, lowering tariffs, abandoning foreign exchange controls. These countries were forced to play "casino capitalism" under the rules of the West, effectively serving themselves on a plate for the developed countries to consume (Strange 1997). The Asian Financial Crisis in 1997 is a case in point when the central banks of Indonesia, Thailand and the Philippines were attacked by Western-led hedge funds.

This paper begins by asking how dependency is being constructed under the Western system and the mechanisms through which peripheral states are being exploited. At the same time, answers need to be found why the affected countries cannot reject the approach from the West? This leads us to examine the early resistance signified by the Bandung Conference in 1955, which was attended by twenty-nine countries from Africa and Asia. Although the conference made many headlines, the occasion proved to be more rhetoric than realistic as it failed arrest the continuous exploitation by the West. Globalisation expands the reach of capitalism to even the communist and socialist states. If the development of developing countries is structurally tied to the Western economic system, then these countries will remain within the shadow of western capitalism. To break away from the dependency orbit, a new south-south dialogue needs to be constructed.

This paper posits that the failure of the Bandung initiative was boiled down to the lack of leadership. In 1955, there was no participant from the global south who could lead a movement to break from the Western dependence. Yet, with the rapid transformation of China's economic fortunes, China has the potential to be the flag carrier for a new Bandung initiative. Based on the foundations laid down in the Bandung Conference, this paper argues that the virtues prescribed by Confucianism hold the key to unify the South, to set a path for south-south cooperation that leads to genuine development of these countries.

\section{Theoretical argument: dependency as a result of Western ideology domination}

Following the Age of Enlightenment in the $18^{\text {th }}$ Century, the agrarian society was rapidly being transformed by scientific discoveries which propelled a rapid phase of industrialisation across Europe. Specialisation spurred increase in productivity. To facilitate industrialisation and specialisation, segregation of ownership and stewardship advanced the development of capitalism. Early day capitalism was mainly geared towards the production of consumable goods. European societies were transformed from feudalism to political economies. The increase in productivity, while brought wealth to the industrialists, also presented a big problem to the governments, they needed a bigger market to fill the increased capacity. To secure more markets, they ventured abroad, driven by imperialism in ideology but implementing colonialism in practice. Larrain (1989: 3-17) described the period 17001860 as the era of "competitive capitalism", and was followed by the "age of imperialism" in 1860-1945, developed to the stage of "late capitalism" in 1945-1966, and degenerated into "deceleration and crisis" in 1966-1980. Throughout the transitions from 1700 to 1980, Larrain saw the expansion of capitalism was the culprit for dependency. In his seminal book Capital, Marx (1818-1883) believed free capitalism would eventually create 
monopolies. Agreeing with Marx, Lenin (1870-1924) claimed that monopolistic exploit could extend beyond national borders, development prompted by capitalism would become "capitalist imperialism" at the highest stage of capitalism (Lenin, 1916:83). According to Lenin, as long as development is driven by capitalism, imperialism is inevitable.

Prebisch (1959) confirmed Lenin's concerns in the 1950's study carried out by the United Nations Economic Commission for Latin America (ECLA). Prebisch found that whilst the industrialized countries got richer, the underdeveloped countries in Latin America got poorer even though trade between them increased. His offered a very simple explanation: poor countries exported their primary resources to the rich countries, the rich countries used these raw materials to manufacture consumer goods and then sell back to the poor countries at value-added costs. Consequently, the poor countries would always end up with trade deficits. Prebisch has lifted the curtain of the debate on core and peripheral states, and set the stage for dependency to be played out behind a neoimperialism and neo-colonialism landscape.

After the ELCA study, dependency theorists like Frank (1972), Cardoso and Faletto (1979), continued with Prebisch's inquiry on the unfair relationship between core and peripheral states. Wallerstein (1974) expanded on the duality of core-peripheral relationship by adding semi-peripheral states in his world system theory. Whilst dependency theory attracted attention in the critical discourse, it was neo-liberalism that was running the show in the international arena. Friedman (1962), together with his Chicago School of economics, advocated monetarism and overturned the Keynesian doctrines. US President Ronald Reagan and UK Prime Minister Margaret Thatcher were among his disciples and helped to advance global trade on western terms and structures. Although Amin (1974) and Emmanuel (1972) continued the dependency debate with their unequal exchange theories, there is no doubt that in reality, the discourse on dependency stayed within the academic circle and never quite made it to the policy level, because like economic dependency, the moral high ground of representations is likewise being occupied by the dominant states. As Escobar (1995: 5) applying Foucault's work on the dynamics of discourse and power in the representation of social reality pointedly claimed, the "colonization of reality" makes possible "a certain order of discourse produces permissible modes of being and thinking while disqualifying and even making others impossible". Consequently, the developed states never acknowledge the fact that dependency is a problem. The discourse on dependency among western politicians is relatively muted. Neoliberalist ideals are still being implemented as foreign policies in the form of Washington Consensus well beyond the imperial and colonial eras and into the neo-colonial $21^{\text {st }}$ Century.

After the end of the Cold War, the US has become the undisputed global hegemon. Fukuyama (1992) was able to declare the End of History with liberal democracy as the ultimate form of governance. Ideologically claiming the moral high ground, the West set the structure of the global financial system, which is also regulated by the West, to reinforce the doctrine of liberal democracy at the expense of creating dependency in the developing world. Consequently, aid from the US is made conditional upon the recipients introducing liberal democratic reforms under the doctrine of the Washington Consensus. Yet, following the 911 terrorist attack on American soils in 2001, former US President George Bush had to ask "Why do they hate us?" a The US sub-prime crisis ultimately triggered the question of whether liberal democracy should be the universal norm of governances. 


\section{The Bandung Conference in 1955 - Peaceful Co-existence?}

Against the background of the Cold War, many Asian and African countries were caught between a polarised world that was divided by ideology, development was marginalised. Calling for economic and cultural cooperation, and preventing Western colonialism, twenty-nine countries congregated in Bandung, Indonesia, on April 18-24 1955 to chart the path for coexistence. The seven-day conference ended with the issue of a 10-point joint declaration, which called for the respect for fundamental human rights; respect for the sovereignty and territorial integrity of all nations; recognition of equality of races and nations irrespective of size; non-intervention of another country's internal affairs; respect the right of each country to defend itself; abstention from collective defence to serve the interests of big powers and abstention from pressuring other countries; refraining from acts or threats of aggression against other countries; settlement of disputes through peaceful means; promotion of mutual interests and cooperation; and respect for justice and international obligations ${ }^{\mathrm{b}}$.

However, soon after the conference, the two Vietnams were at war with each other in 1959; the Sino-India war broke out in; and Indonesia, the host of the conference, declared a policy of confrontation against the newly-formed Malaysia in 1964 (Finnane 2010: 1). Therefore, whilst the Bandung Conference can be seen as an ambitious project to galvanise the global south, in reality, the coalition was very fragile, the joint declaration of peacefulco-existence was mere political rhetoric.

Indeed, the conference came to an immediate deadlock on the first day after human rights was tabled for discussion (Burke 2010: 33-34). The successful conclusion of the conference was the result of the masterful diplomatic skill of Chinese Premier Zhou Enlai, who managed to present China's stance in a conciliatory tone (Burke 2010; Finnane 2010; Mackie 2005; Roy 1998). If the success of the Bandung conference was boiled down to the charisma of one man, the failure to implement the joint declaration could also be attributed to the absence of leadership.

The death of Zhou Enlai in January 1976 and Mao Zedong eight months later brought an end to an era that was saddled with decolonialisation and Cold War confrontations. In its wake was the rapid transformation of China's fortunes under reforms introduced by Deng Xiaoping. If the failure of Bandung was attributed to a lack of leadership, could the rise of China present a second coming of Bandung to unite the global south and free them from western dependency?

\section{The rise of China and the missed chances}

China experienced rapid economic growth after the introduction of open-door policy in the post-Mao era. In the three decades that followed, China has propelled itself to become the second largest economy in the world with nominal GDP stood at \$8.2 trillion in 2012 (US \$16.2 trillion; Japan \$6.0 trillion); for the same year, it ranked first in export at \$2.0 trillion (US \$1.6 trillion; Germany \$1.5 trillion); second in import at \$1.8 trillion (US \$2.4 trillion; Germany \$1.3 trillion); it possessed the highest foreign reserve in the world at $\$ 3.2$ trillion, almost three times the second largest reserve country Japan at \$1.2 trillion ${ }^{\mathrm{c}}$. Amidst the rise in China's status comes the Chinese threat, the country has the most number of active troops and it possesses nuclear weapons ${ }^{d}$. The history of China is scarred by imperial invasions in the last two centuries. Thus, the question of whether 
China can rise peacefully becomes a concern to its neighbor and the West. To avoid giving the wrong impression that China is no different from Western powers when they reached for global hegemony, China subsequently changed its claim on peaceful rise to peaceful development.

China was very pragmatic in its initial development. Deng's thinking was heavily influenced by sixth century BC philosopher Lao Tzu, who started Taoism (Shen 2010: 5-6). Taoism emphasizes on the virtues of staying in a low profile and be patient. These Taoist principles laid the undertone of China's foreign policy under Deng. Subsequent leaders Jiang Zemin and Hu Jintao fine-tuned Deng's policy in order to meet a changing world order, but they deviated from Deng's Taoist diplomacy and missed the opportunity to position China as the flag-carrier of south-south cooperation.

After the Tiananmen Square incident in 1989, China urgently needed to repair her battered image, thus prompted Deng to lay down his famous foreign policy dictums of lengjing guancha (冷靜觀察; calmly observe the situations); shouzhu zhendi (穩住陣地; secure footing); chenzhou yingfu (沉著應付; cope changes with calm, vigilance and confidence); taoguang yanghui (鞱光養晦; conceal capacities and bide time); shanyu shouzhou (善于守拙; skillfully keep a low profile); and juebu dangtou (决不當頭; avoid sticking head out) (Gong et al. 1998). However, after securing a sound economic base, Deng's successor Jiang Zemin introduced the concept of "great power strategy" by adding grasping opportunities and making the best use of a situation to Deng's initial ideas. Jiang set China on a more adventurous course that drove towards great power status. When Jiang transferred leadership to $\mathrm{Hu}$ Jintao in 2003, China was a more confident nation enjoying resounding economic success and international praise on its handling of the Asia financial crisis by not devaluing the renminbi. Hu began to work on "peaceful development", "harmonious international order" and "global responsibility". Under the Hu doctrine, four interrelated initiatives were introduced. First, China endeavored to maintain good relationship with the US and other international powers. Second, as the global order began to revolve around a G2 scenario, China seeked to actively promote diplomacy with her neighbours to create a buffer against US pressure. Third, China accelerated her involvement in regional and international organizations to promote economic development and security. Finally, in order to project a positive image abroad, China began to undertake greater international responsibilities by actively participating in United Nations peace missions.

If China were to become the flag-carrier of a new south-south cooperation initiative, several questions need to be addressed. First, has China set up a new model of development without having to repeat colonialism carried out by the old imperialists? Secondly, has China illuminated a new way for great power to emerge, that there should be no confrontation, and no Cold War mentality? Finally, has China exhibited a new model of social control through promoting a harmonious society?

\section{Has China established a new model of development?}

In the $19^{\text {th }}$ Century many western powers colonized countries in Latin America, Africa and Asia in order to secure raw materials and open up new markets. Many neighbors of China in Asia have colonial past, and hence they are rightly concerned about China's rise. However, during China's modernization, China has not taken any colony. China modernized through reforming state-owned enterprises and by attracting foreign investments. Overseas 
Chinese from Hong Kong and Taiwan have played an important role in the early modernization process. Through comparative advantage, entirely in accordance with the Heckscher and Ohlin theory that a country should concentrate on its factors of endowment, China specialized in labor-intensive manufacturing goods and export to the US and Europe, while imports capital from them in return. New markets have been opened because of cost advantage, and not by forceful colonization. In securing raw materials, China buys from Africa, Latin America and the Middle East. In Africa, China helps countries to build roads, hospitals and schools, provides cheap loans, and write off debts, in order to secure resource concessions. Providing development aid to under-developed countries with no precondition, synonymized under Beijing Consensus, forms a strong contrast to the Washington Consensus, which requires the recipient country to introduce democracy and market reforms. By adopting multilateral diplomacy and through tightening relationships with African countries and ASEAN neighbors, China has become a status quo power alongside the US.

However, not everyone agrees with China's practice in Africa. In 2011, US Foreign Secretary Hilary Clinton pointedly accused China practicing neo-colonialism in the African continent ${ }^{\mathrm{e}}$. These practices allowed authoritarian regimes to take hold, corruptions to go unchecked, democratic development on the reverse. Therefore, China's new model of development equates to just buying up crony states. However, China is doing much more than just buying resources and selling cheap goods to Africa. In 2004, China provided US\$2 billion in loan and aid to Angola that allowed the country to reject a hugely unpopular IMF rescue package that involved opening up the market and abolishing local trade unions ${ }^{\mathrm{f}}$. In Sudan between 1997 and 2007, China had granted the country over US\$550 million in interest-free loans; in 2003 China provided US\$930 million for the construction of the Merower Dam to help to improve the local irrigation and provide hydro-electricity; and in 2008 China supplied further US $\$ 2.8$ million in humanitarian aid for the country ${ }^{g}$. In 2009, China provided the bulk of the US\$650 million required to build the Djibloho Hydropower Project in Equatorial Guinea ${ }^{\text {h }}$. By 2009, China had financed a total of 884 projects in Africa, including 142 agricultural projects, 71 schools, 54 hospitals, 53 sports complexes, and 62 conference centers ${ }^{i}$. While there may be other contributing factors, Chinese involvement in Africa coincided with an overall improvement in social conditions in many African countries. Annual GDP growth in Sub-Saharan African averaged 5.5\% per annum during the decade 2000 to 2010 (Figure 1). Through building more schools, the adult literacy rate has improved from $47 \%$ in 2000 to $66 \%$ in 2010; youth (age 15-24) literacy rate jumped from $56 \%$ to $78 \%$ in the same period (Table 1). Infant mortality rate in West and Central Africa dropped from 196 per 1,000 live birth to 143 in the twenty years between 1990 and 2010; Eastern and Southern Africa likewise recorded a drop from 156 to 98 during the same period (Figure 2).

\section{Has China illuminated a new way for a great power to emerge?}

Through multilateral diplomacy, China has increased its political space in the international arena. In the Korean peninsula, China played an active role in bringing about the Six Party Talks to ease the tension caused by North Korea's provocative actions. With the exception of India, China has settled all land territorial disputes. It has created the Shanghai Cooperation Organization to foster security cooperation in Central Asia. With its Asian 


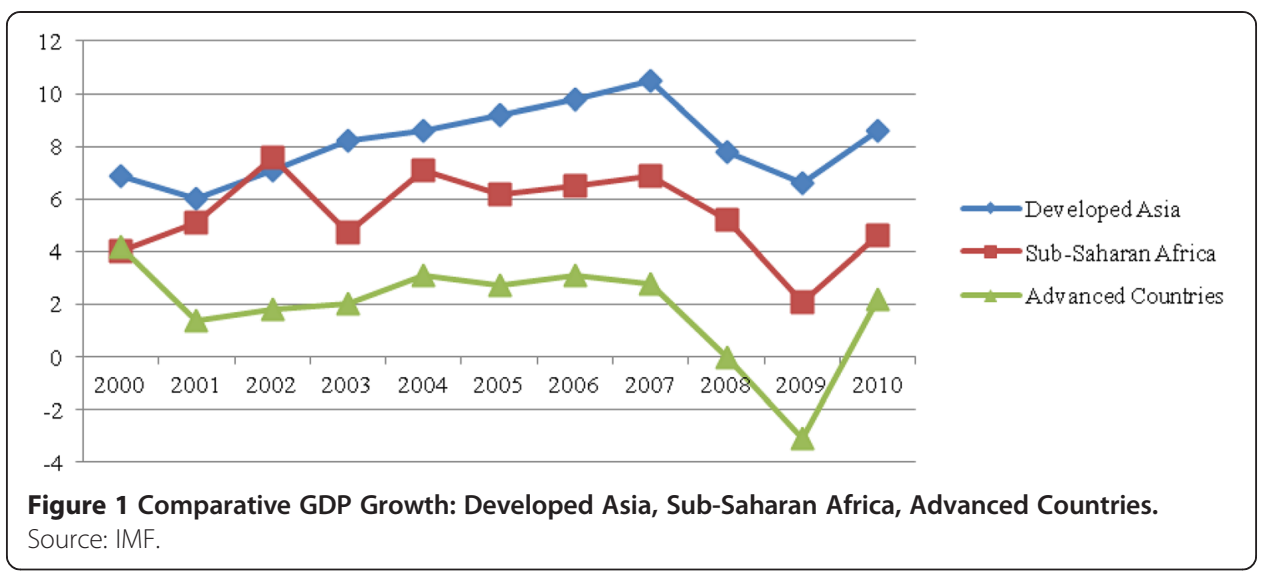

neighbors, China became a dialogue partner in 1996, participated in ASEAN +3 in 1997, signed the Treaty of Amity and Cooperation in 2003 and issued Joint Declaration on Strategic Partnership for Peace and Prosperity in 2003. Even the accidental bombing of its embassy in Belgrade by US-led NATO forces was handled calmly with reserve. All these strongly support the claim that China wants to avoid confrontation, and through multilateral dialogues prevent the world slipping back to Cold War confrontation. However, in areas that touched on China's core interests, China has been more assertive. In dealing with maritime territorial disputes, China has intensified its war of words with other claimants, rejected US intervention and insisted on bilateral talks to solve the disputes. The Daioyu Islands (the Senkaku Islands according to Japan) is the source of constant conflict with Japan.

\section{Has China developed a new approach to achieve harmony?}

After joining the UN in 1971, China initially took a stance of non-participation due to skepticism on the interventional policy. However, it became more active since the 1980's, and began participating in peacekeeping missions in the 1990's. From taking part as observer in 1989 in Namibia, to providing engineering battalion in Cambodia in 1992, sending medical troops to Congo in 2003, policing Haiti in 2004, sending engineering battalion to Lebanon in 2006, China has taken on a bigger responsibility as expected from a great power. Aside from the joint operations with the UN, China even earned the status of a responsible actor when it refused to devalue the RMB during the Asia financial crisis in 1997, which would have certainly sent Asia to another tailspin. However, there will always be questions asked on whether China has really created a harmonious society. Human rights abuse and lack of transparency in the rules of law have undermined China's claim. Its support to authoritarian regimes in Myanmar and Africa cannot arguably fit the description of promoting a harmonious world.

Table 1 Adult literacy rate in Africa

\begin{tabular}{|c|c|c|c|c|c|c|c|}
\hline Year & $\begin{array}{l}\% \text { of Pop. } \\
\text { With no } \\
\text { schooling }\end{array}$ & $\begin{array}{l}\% \text { of Pop. } \\
\text { Primary } \\
\text { Edu. }\end{array}$ & $\begin{array}{l}\text { \%of Pop. } \\
\text { 2ndary } \\
\text { Edu. }\end{array}$ & $\begin{array}{l}\% \text { of Pop. } \\
\text { tertiary } \\
\text { Edu. }\end{array}$ & $\begin{array}{l}\text { Literacy } \\
\text { Rate Youth } \\
15-24\end{array}$ & $\begin{array}{l}\text { Literacy } \\
\text { Rate Entire } \\
\text { Pop. }\end{array}$ & $\begin{array}{l}\text { Avg. } \\
\text { Years of } \\
\text { Edu. }\end{array}$ \\
\hline 2000 & 39.80 & 16.55 & 9.46 & 1.53 & 56.28 & 47.13 & 4.71 \\
\hline 2005 & 35.96 & 17.79 & 10.59 & 1.86 & 71.20 & 59.38 & 5.15 \\
\hline 2010 & 32.27 & 19.89 & 11.03 & 2.26 & 77.84 & 66.46 & 5.58 \\
\hline
\end{tabular}

Source: Barro and Lee (2010), and UNESCO. 


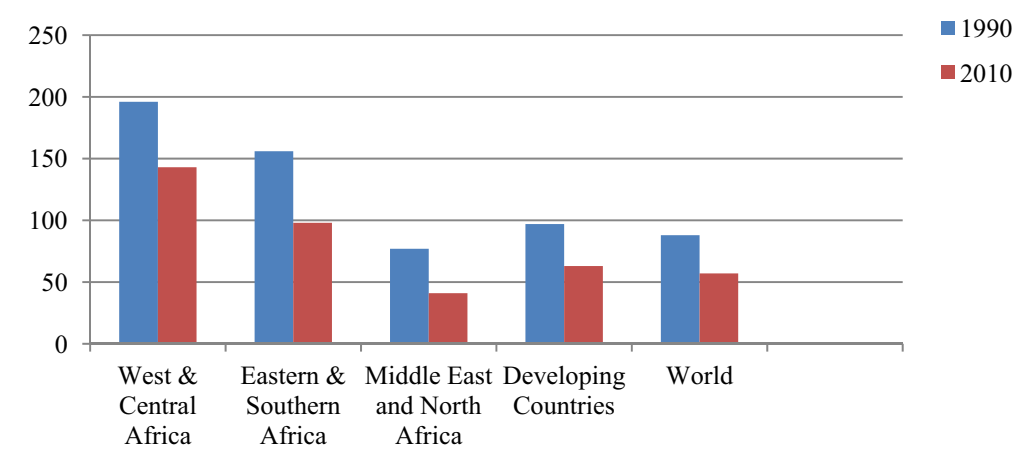

Figure 2 Under-5 Mortality Rates (per 1,000 Live Birth). Source: UN Inter-agency Group for Child Mortality Estimation 2011.

\section{The missed chances}

Having established herself as the second largest economy in the world, behaving responsibly during the Asian Financial Crisis by not devaluing the Renminbi, and taking a reconciliatory stance in the bombing of its Belgrade embassy towards NATO and the US, China could have accumulated enough goodwill to substantiate her claim of peaceful rise and secure her position to lead the global South towards a development path that is not orbiting around the West. However, China has been let down by its lack of disciplines when investing abroad, often being accused of corruption, and squeezing out local job market and production. Her increasingly assertiveness in territorial issues coupled with a lack of transparency in military expansion have alerted her Asian neighbours to guard against a rising dragon. Therefore, far from drawing the global South together, China has casted herself away from them, Myanmar's sudden leaning towards the US is a case in point. Unless China reposition herself in the global South, she may one day rue about the missed chances and feel increasingly contained by the West (Wong \& Yue, 2014).

\section{The embedded realism in Taoism and the Promise of Confucianism}

China transited from Deng's Taoist diplomacy to Jiang's engagement policy and reached Hu's harmonious society. There are variations to the original doctrine of concealing capacities and bidding time, however, Deng had also provided that when opportunity arise, China should be “you suo zuo wei” (有所作為; proactive and make achievements).

To challenge the mainstream Western neo-liberalism as development model for underdeveloped countries, China believes her own development model of social capitalism, or capitalism with Chinese characteristics that relies on investment, trade and technology instead of western aid, can be duplicated abroad (Brautigam 2009: 312). Consequently, under Beijing Consensus, China is willing to provide financial assistance to underdeveloped countries with no string attached. Beijing Consensus and Washington Consensus went head-to-head in Angola during 2004. Frustrated by the stiff demands from the IMF to introduce liberal reforms before providing much needed financial aid, the Angola government turned to China in a $\$ 2$ billion oil-backed loan. Aguinaldo Jaime, the defacto Angola deputy prime minister summed up the sentiment of the country towards Western aid, "If you say to a country, 'We'll reward you when things are perfectly O.K', the country will say, 'When things are perfectly O.K., we won't need you anymore." ' . Yet, the Beijing Consensus is not without its critics, most noticeably from the US which claims China is 
basically practising neo-colonialism and the Chinese benevolence comes with a price of ridding off the recipient country's natural resources. Also, the no-question-asked developmental aid allows corrupted regimes to continue depriving their citizens from reaping the benefits of development. Whereas neo-liberalism under Washington Consensus reinforces the dependency between peripheral states and cores states, the aid-for-asset model under Beijing Consensus creates another form of dependency, regime survival for the weak states.

Up to the turn of the millennium, China had gone on well with her Asian neighbours and African friends. Whilst the West was quick to blame China on the way she quashed the Tiananmen student protest and sanctions swiftly followed, her Asian neighbours upheld the peaceful coexistence principle of non-interference and provided the diplomatic space for the Beijing government. In reciprocal, when the Asian Financial Crisis hit Indonesia, Thailand, the Philippines and Malaysia, China did not follow the rest to devalue its currency and held the RMB firm at the expense of potentially losing out on exports. Outside the region, when the Chinese embassy in Belgrade was destroyed by US-led NATO forces in 1999, China was refrained enough to prevent the incident from escalating to a major confrontation with the US even though its sovereignty was clearly being infringed ${ }^{\mathrm{k}}$. The Hainan air-crash incident in 2001 was another case to demonstrate Chinese leaders were eager to promote peace and harmony even though one of its fighter pilots was killed trying to intercept a US surveillance plane ${ }^{1}$. Yet, why the West and China's neighbours are so worried about the rise of China, and why the aid provided by China to under-developed countries were viewed with such skepticism?

To appreciate the concerns one must understand the strategic culture of China. Behind the apparent peaceful Taoism that was embraced by Deng in his foreign policy is a hidden realist agenda. Both Johnston (1995) and Wang (2011) have argued that history has shown that China was an aggressor when her relative military power was stronger than her neighbours. Indeed, Taoism concerns about the balance of power, the interconnected and yet opposing relationship between yin (陰) and yang (陽), but balance of power is very much a realist terminology. Whilst the West is fascinated by the wisdom of the Art of War (孫子兵法) written by the great Chinese strategist Sun Tze, they are also informed of the Chinese strategic culture of Wo Xin Chang Dan (臥薪嘗膽), which means enduring self-imposed hardships in order to strengthen and prepare the resolve of a person to realize his ambition. The history behind Wo Xin Chang Dan described a poetic justice took place during the Spring Autumn period (770-476BC) when the State of Wu was at war with the State of Yue. The King of the State of Wu was wounded and subsequently died in battle. His son Fu Chai avenged the defeat of his father by conquering and capturing his counterpart Guo Jian, and held him under imprisonment in Wu territory. In order to humiliate and demoralize Guo Jian, Fu forced Guo to live in shameful conditions. Guo endured the mental torture and years later secured his release back to the State of Yue after swearing loyalty to Fu. Once back to his own state, Guo was very patient in hiding his capability because the State of Wu was still far too strong for the State of Yue, but secretly he trained an army. In order to remind himself of the humiliation as a hostage, he sacrificed sleeping on a comfortable bed, but instead slept on a stack of firewood. Before he had dinner and went to bed he tasted the bitterness of the gall-bladder that was hung on top of his bed to remind himself of the painful experience as a captive, hence the term Wo Xin Chang Dan. When opportunity arose, Gou launched attack on Fu, caught him by surprise and wiped out the State of Wu in one stroke. 
Juxtaposing Wo Xin Chang Dan with the policy dictums of Deng, those of calmly observe the situations; secure footing; cope changes with confidence; conceal capacities and buy time; skillfully keep a low profile; and avoid sticking head out, one cannot resist but to draw parallels and ask the ultimate question: will China avenge on her humiliation by the invasion of the Eight-Nation Alliance (八國聯軍), that consisted of AustriaHungry, France, Germany, Italy, Japan, Russia, the United Kingdom, and the United States?

If there is embedded realism in Taoism, how is it being manifested in the foreign policy of Deng and his subsequent successors? One of the most ambiguous phrases in the policy dictum of Deng is taoguang yanghui (韜光養晦), or to conceal capacities and bide time. Why did China need to conceal capacities, and bide time to do what? A quick reminder on how Deng dealt with the territorial dispute in the East China Sea with Japan and the territorial dispute with her ASEAN neighbours in the South China Sea may illuminate the traits of taoguang yanghui and hidden realism in the foreign policy of China.

During a visit to Japan in October 1978, Deng told the Japanese Prime Minister Takeo Fukuda that the two countries should focus on promoting mutual interests instead of arguing over Diaoyu Islands (Senkaku Islands to the Japanese) ${ }^{m}$. In May 1979, when meeting with Suzuki Kenko, a member from the lower house of the Japanese Diet, Deng raised for the first time the concept of "setting aside dispute and pursuing joint development" ${ }^{\text {n }}$.

Deng repeated the "setting aside dispute and pursuing joint development" concept on her ASEAN neighbours. In June 1986, on the dispute over Nansha Islands, Deng said to visiting Filipino Vice President Laurel, "we should leave aside the issue of the Nansha Islands for a while. We should not let this issue stand in the way of China's friendship with the Philippines and with other countries." o In April 1988, Deng told visiting Filipino President Aquino, "in view of the friendly relations between our two countries, we can set aside this issue for the time being and take the approach of pursuing joint development" $\mathrm{P}$.

In the 70's and 80's, the reform in China was just underway. The economy was recovering from the Cultural Revolution wreckage. China had neither the capacity nor the capability to demand settlement on the disputed territories. Therefore, setting aside dispute represented the most prudent approach. However, when the comprehensive power of China rose to a level that led international relations commentators dubbed the G2 era, ${ }^{\mathrm{q}}$ China became more assertive on her regional neighbours, resulting in escalating tensions in the territorial disputes. Setting against a strategic culture of Wo Xin Chang Dan, the Taoism diplomacy of taoguang yanghui could be seen in the light of hiding capacities so that no one would worry about the threat of China rise until its comprehensive power reached a critical mass, and bidding time to wait for opportunity to strike. The sub-prime credit crisis in the US in 2008 and the sovereign debt crisis in Europe presented China with the chance to raise the phoenix from the ashes. The arrogance of Chinese leaders led the West and Asia to believe the China threat is clear and present.

Defending China's policy in Africa, Li (2011) has highlighted the four notions of Chinese cultural values of benevolence, forbearance, trustfulness and equality to argue that the noninterference policy of China in Africa could produce a win-win situation for both countries.

Furthermore, Yan (2011) argued that the West has misunderstood China. While the historical culture of China aspired to Daoism, China's traditional worldview was simultaneously operated under a system of Confucian values (Bell \& Metz 2011). Ontologically derived from Yijing (易經) (Cheng 2011b), Confucianism, advocated by 
Chinese philosopher Confucius (551-479 B.C.), provides an ethical socio-political codes of conduct that emphasize on respect. Under Confucianism, people should respect those who are senior to them. As Tian (heaven) (天) was deemed to be above everything, Chinese sovereigns, who were referred to as Tian-zi and claimed to be the Sons of Tian (天子), therefore logically inherited unquestionable and indisputable political legitimacy to govern (Bell \& Metz, 2011). However, Confucianism also provides that the right to power could be withdrawn from the Son of Tian if he failed to embrace and practice Confucian values that consist of Humaneness (仁), Righteousness (義), Propriety (禮), Knowledge (智) and Integrity (信). Under such scenario, there would be a change in dynasty until a new Tian-zi emerged to uphold the moral values.

Extending beyond Chinese society, Confucianism justified and rationalized inequality in the traditional Chinese tributary system under the Tian-xia (天下) worldview (Qin 2010). Tian-xia means space under the heaven. Sharing the same Tian, the power of Tian-zi could go beyond geographical boundaries to be exercised over tributary states, whose people should aspire to the Chinese culture underpinned by Confucian values. The external reach of Tian-zi was structured under three Chinese philosophical concepts of holism, Datong (大同) and order (Qin 2010: 41-42). These concepts underline the key fundamental differences between Chinese Confucianism worldview and Western realism traditions.

Holism means there should be no separation between "I" and "we", or "self" and "other". It has two dimensions: the temporal dimension that structures like the relationship between great-grandfather with the great-grandson, and the spatial dimension views like at the center of a ripple with concentric rings spreading out. Under this holism worldview, there is nothing opposite. This concept is fundamentally different from Western realist's interpretation of the world that conflicts between states are inevitable.

Datong, meaning great harmony, refers to the trinity where human and nature, ideal and reality, moral and material, meet as a harmonious whole (Qin 2010: 42). In contrast with realism which assumes the world is anarchic, under Datong, a harmonious world was not only natural but inevitable. In a Confucian tributary system, order was different from the Hobbesian jungle where men were equal but because of survival had to be hostile to each other, nor was it the same as in a Lockean society where people were equal but they had to be competitive to stay ahead of one another, and it was not a Kantian culture in which people were equal and friendly to each other.

The order under a Confucian tributary system was like the relationship between father and son, unequal but benign out of respect (Qin 2010: 42). Indeed, a Confucian world order is quite different from the landscape painted by Western international relations theories of realism, liberalism and constructivism (Yue 2014). Whereas realism leads to hegemony, liberalism causes interdependency, and constructivism encourages regionalism, Confucianism promotes a harmonious world under an asymmetrical system crafted out of mutual respect (Table 2). Precisely because of these different perspectives which are deeply rooted in Chinese culture, Confucianism could potentially illuminate an alternative approach towards south-south cooperation that is free from dominance and dependency.

\section{Operational mechanism of Confucianism in South-South Cooperation}

In Western society, harmony is regulated by the rule of law. It is an error-control feedback system, if a person breaks the law, he will be sent to the court for judgement and 
Table 2 Comparing Confucianism with realism, liberalism and constructivism

\begin{tabular}{|c|c|c|c|c|}
\hline & Confucianism & Realism & Liberalism & Constructivism \\
\hline $\begin{array}{l}\text { Level of } \\
\text { analysis }\end{array}$ & Individual & State & $\begin{array}{l}\text { State }+ \\
\text { Non-State Actors }\end{array}$ & $\begin{array}{l}\text { Agency Structural } \\
\text { Dialectic }\end{array}$ \\
\hline Key Tenets & $\begin{array}{l}\text { Humaneness, } \\
\text { Righteousness, Propriety, } \\
\text { Knowledge, Integrity }\end{array}$ & $\begin{array}{l}\text { Statism, Survival, } \\
\text { Self-Help }\end{array}$ & $\begin{array}{l}\text { Comparative } \\
\text { Advantage }\end{array}$ & Norms \\
\hline \multirow[t]{3}{*}{$\begin{array}{l}\text { System } \\
\text { outcomes }\end{array}$} & $\begin{array}{l}\text { Under holism: } \\
\text { nothing opposite }\end{array}$ & \multirow{3}{*}{$\begin{array}{l}\text { Hegemony, } \\
\text { Zero-sum game: } \\
\text { conflict inevitable }\end{array}$} & \multirow[t]{3}{*}{$\begin{array}{l}\text { Interdependence, } \\
\text { Trade war }\end{array}$} & \multirow[t]{3}{*}{ Regionalism } \\
\hline & $\begin{array}{l}\text { Under Datong: } \\
\text { A harmonious world }\end{array}$ & & & \\
\hline & $\begin{array}{l}\text { Hierarchy/Order: } \\
\text { Unequal but benign }\end{array}$ & & & \\
\hline
\end{tabular}

punishment will follow if found guilty (Rose, 2004). Conversely, Confucianism is a selfcontrol internal moral compass. Whilst Confucianism is a very broad concept, for the purpose of understanding its role in China's foreign relations policy, the paper loosely uses Confucianism to describe the moral universe of the self which is based on goodness. This approach is consistent with other writings which deal with China's external policies ( $\mathrm{Li}$, 2011; Cheng, 2011a). Confucius installed Propriety ( $l i$; 禮) as the basis to achieve harmony, and therefore Propriety is the foundation for political rule (Cheng 2011b). In the Analects (Lunyu 《論語》), which contains the main teachings of Confucius, it said:

"Guided by dictates of political authority, and regulated by punishment, people can get by without violating the law but have no sense of shame; guided by virtue, and regulated by li, people will have sense of shame and a standard of personal development" (Analects (Lunyu 《論語》2:3, in Cheng 2011b: 12).

Propriety ( $l i$; 禮) is underpinned by Humaneness (Ren; 仁). The Chinese character of Ren is symbolically made up of two components: humanity and the togetherness of two human beings (Cheng 2011b: 12). To be considered Ren, a person must place himself into the position of others so that he can empathize and sympathize the others before taking any action. Ren is therefore an internal feeling generated from the inner consciousness of a person (Cheng 2011b: 16).

If Ren is the internal moral control, then Righteousness ( $y i$; 義), represents “the proper share one should receive from a just distribution of rights and benefits, duties, and responsibilities" (Cheng 2011b: 16). Thus, Righteousness is the external expression of morality. Together with Propriety ( $l i$; 禮) and Humaneness (Ren; 仁), the three virtues combined to produce Knowledge ( $z h i$; 智). Knowledge here does not simply mean knowing things epistemologically, but the knowledge of doing the rights thing morally, guided by Propriety ( $l i$; 禮), Righteousness ( $y i$; 義), and Humaneness (Ren; 仁). Thus “zhi is knowledge of ends and the ability to discern the means to given ends" (Cheng 2011b: 17). With Knowledge comes Integrity (xin; 信), or trust. Trust is not a given virtue, it has been gained from a combination of subjective feeling and objective observation of trustworthiness. In Confucian ethics, trust is generated from inside a person through Propriety ( $l i$; 禮), Righteousness ( $y i$; 義), Humaneness (Ren; 仁), and Knowledge ( $z h i$; 智), trust in oneself will induce trust from others, thus producing Harmony (he; 和), or a harmonious world. Therefore, according to Confucius, a ruler must establish trust, for "there is no way to establish oneself without trust from people" (Lunyu 《論語》12:7, in Cheng 2011b: 27). To be sure, according to Confucius, harmony is achieved from internal self. This is the 
fundamental difference from the Western concept of enforcement through rule of law and punishment (Yue 2014) (Figure 3).

Why has Confucianism failed to deliver its potential as a non-Western international relations theory? According to Cheng (2011a: 1), "after the May $4^{\text {th }}$ Movement of 1919 (Wusi Yundong 五四運動), Confucianism lost much of its moral appeal and political authority and entered into a kind of limbo". Post-Tiananmen Chinese leadership justified their continuous grab on power by sustaining the economic miracle. To push for growth, the leadership have turned blind eyes on corruption, rules of law and human rights, effectively abandoning all Confucian values. Therefore, aid provided under the Beijing Consensus is naturally being treated with suspicions (Alden 2007; Davies 2007; Sautman 2007; Taylor 2006). Ramos (2004), who coined the term Beijing Consensus, suggested that China's rise in economic power had allowed her to play an important role in helping other developing countries to develop. In 2009 alone, China provided RMB250 billion in aid, of which $41 \%$ was in grant, 30\% in interest-free loans, and 29\% in concessional loans (Information of the State Council and the People's Republic of China 2011). China's unconditional aid to under-developed states in Africa has prompted the former US Secretary of State Hillary Clinton to describe it as creeping "new colonialism" during her three-nation tour of the African continent in June 2011. Clinton pointed out "it is easy to come in, take out natural resources, pay off leaders and leave, and when you leave, you don't leave much behind for the people who are there. We don't want to see a new colonialism in Africa" ${ }^{\text {r }}$.

China has risen rapidly in the last three decades, allowing the country to be more influential in global affairs, but China has also become more assertive in regional conflicts as can be seen in her attitudes towards the South China Sea territorial dispute. China's economic and military strengths have alarmed her neighbours, leading to fears that the China rise cannot be peaceful. When hard power is seen to be threatening, China desperately needs to project her soft power to balance her international image. Soft power means co-operating with people in getting what you want, not by coercion, and it is not the same as influence or persuasion, but possesses the ability to attract and leads to acquiescence (Nye 2004: 5-6). The question of whether Confucianism has a postmodern role in guiding state behavior thus becomes more urgent. Echoing Cheng's (2011a: 1) view, reviving Confucianism as a moral-political philosophy and by incorporating the moral values into China's foreign policy has the potential to provide an alternative to Western-styled international relations.

\section{Policy implication: beyond dependency - a new Bandung initiative and its critiques}

This paper posits that the failure of the 1955 Bandung Conference was boiled down to the absence of a dominant actor in the global south. Therefore, when set within a Cold War polarized context, the global south were caught between the struggles of great power rivalries, thus south-south cooperation never got off the ground. However, the rise in the comprehensive power of China may present another chance for a new Bandung initiative.

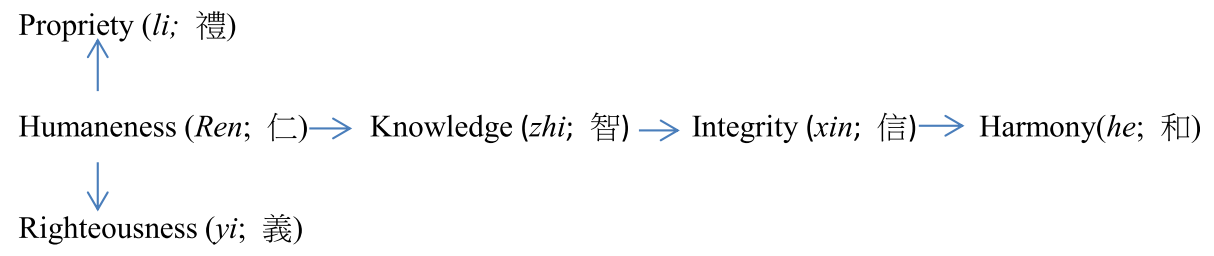


This paper acknowledges that the suggestion of putting China in charge of the southsouth cooperation bandwagon is likely to fall into the same trap as realists have done to justify domination based on a hegemonic stability discourse $s$. However, this is precisely where decolonization of thoughts may help to contribute to a new international relations paradigm that is epistemologically different from the Western traditions of realism, liberalism and constructivism. Controversially, relationship based on Confucianism is not based on equal footing. Confucianism postulates an asymmetrical relationship built on respect, like a son towards his father; a student towards his teacher. Similar to that of the old Chinese tributary system, China can be potentially installed at the center of a south-south plenary assembly. China, of course, does not possess the automatic right to lead the cause, its leadership must fully embrace the Confucian values, through propriety, righteousness and humaneness to build knowledge, integrity, and ultimately, achieving harmony. During this process, there will be mistakes made, but this merely serves to underline the importance of integrity generated from practicing propriety, righteousness and humaneness.

Whilst this paper is aware that Confucianism is not a static concept $(\mathrm{Ng}$ and Chow, 1999; Sole-Farras, 2014; Tu, 1994), the changing narratives and boundaries should not affect the fundamental philosophical meanings that consist of goodness within the self. Therefore, this paper adopts the views of Zhang (1980-81) and Lauridsen (1988) that Confucianism has "an abstract meaning making them forever relevant, besides the concrete meaning limited by historical circumstances" (Lauridsen, 1988: 27).

Another source of criticism is likely to come from non-Chinese cultural backgrounds, the moral ethics that are advocated by Confucianism may not be applicable to other cultures. Confucianism is not a religion. It does need to convince others to believe in its preaching or values. Confucianism is a moral-political philosophy that set examples for others to follow (Cheng, 2011a). Different from the End of History claim of Fukuyama (1992) and the Clash of Civilisations postulation of Huntington (1997), Confucianism promotes holism to eliminate the "I" and "we" in a world that is separated by ideology and civilization. Therefore, the question of "why do they hate us" would never arise in a Confucian discourse.

\section{Conclusion}

It is never the intention of this paper to claim China has been misunderstood in terms of its foreign policy projection under Beijing Consensus, nor to deny the negative impacts on local societies when resource-led diplomacy is intertwined with rogue regimes, corruptions and human displacements. Quite the contrary, this paper argues that it is because of the failure of China in promoting Confucian values that resulted in backlashes from local communities, but this shortfall should not deny the potential offered by Confucianism as a gravitational pull to galvanise south-south cooperation in a decolonial push away from Western hegemony.

Both Johnston and Wang posit that China would go on offensive in a realist domain. This may be true if we accept the global order is anarchic, and it was certainly the case in the pre-modernity periods when the authors based their investigations. However, in an increasingly globalised world where transnational organisations can play the role to "articulate[ing] problems and conflicts and solve[ing] them" (Galtung, 1980: 425), global 
order is not anarchic. Great power rivalry does not need to be materialised on the battlefield, it can surface on different images, such as trade (trade war), or cultural influence (soft power), Therefore, the global order that we are in today is neither anarchic nor pacific, hence reviving the Confucian moral values may help to navigate in this new uncharted territory.

During the Boao Forum for Asia in 2013, Chinese Premier Xi Jinping outlined a vision for cooperation based on sustainable development, stability against traditional and nontraditional threats, and balancing the interests of all parties ${ }^{t}$. While this may set the terrain for cooperation both within and beyond Asia, a new Bandung initiative requires a much more solid operational framework that should be delinked from the north-south model. Instead, the narrative of a new Bandung initiative on south-south cooperation should go beyond the dependency on the developed economies. China has amassed a staggering US\$3.7 trillion in foreign reserves after twenty years of economic expansion, more than triple the second largest reserve country, Japan (US\$1.2 trillion). The most important and daunting task for China is how to recycle the surplus to other parts of the global south without attracting the labels of neo-colonialism or creating dependency as it has suffered in the past under the Beijing Consensus. Confucianism, as a self-critique to guide own behaviours, offers the potential of a moral compass to navigate towards a new course for south-south cooperation. How to unleash this potential requires coding of Confucian practice, from there we can ascertain where China has fallen short, and where she can improve in order to repair her tainted image. However, coding Confucian practice is beyond the scope of this paper and therefore, it becomes the suggestion of this paper for further research.

The rise of China should neither be seen as a challenge to the US hegemony, nor a disruption to existing global system. Rather, it should be received as a counter-balancing force that offers an alternative development path for developing and under-developed countries that is free from the curse of dependency. There are evidences that China's resource-led investment and aid policies in Africa have improved the economic conditions of those countries. However, China should also be aware that her business ethics have raised concerns in the international community and even encountered rejections in some recipient countries. Therefore, China should promote her soft power through reembracing Confucian values, and to lead the global south towards genuine development that is free from dependency.

\section{Endnotes}

a'George Bush's address to the joint session of Congress and the nation, September 20, 2001. The Washington Post: http://www.washingtonpost.com/wp-srv/nation/specials/attacked/ transcripts/bushaddress_092001.html

${ }^{\mathrm{b}}$ The Final Communique of the Asian-African conference of Bandung (24 April 1955). http://franke.uchicago.edu/Final_Communique_Bandung_1955.pdf

${ }^{\mathrm{c}}$ World Bank statistics

${ }^{\mathrm{d} I n t e r n a t i o n a l ~ I n s t i t u t e ~ f o r ~ S t r a t e g i c ~ S t u d i e s ~(I I S S) ~ M i l i t a r y ~ B a l a n c e ~ R e p o r t ~} 2014$. https://www.iiss.org/en/publications/military-s-balance

${ }^{e}$ During her five-day tour of Africa in June 2011, the then US secretary Hilary Clinton said the world's second largest economy (China) was displaying traits of "neo-colonialism" 
in Africa, and "we saw that during colonial times, it is easy to come in, take out natural resources, pay off leaders and leave.” (Bloomberg News, June 11, 2011, "Clinton chastises China on Internet, African New 'Colonialism”. http://www.bloomberg.com/news/201106-11/clinton-chastises-china-on-internet-african-new-colonialism-.html

f Source: China-Africa Trade and Economic Relationship Annual Report 2010.

gIbid.

hIbid.

${ }^{\text {i Ibid. }}$

jNew York Times, November 19, 2006, “China's African Adventure”. http://www. nytimes.com/2006/11/19/magazine/19china.html?pagewanted=print\&_r=0

kThe Guardian, 17 October 1999, "Nato bombed Chinese deliberately". http://www. theguardian.com/world/1999/oct/17/balkans

${ }^{1}$ CRS Report for Congress, "China-US aircraft collision incident of April 2001: Assessments and Policy Implications". http://www.fas.org/sgp/crs/row/RL30946.pdf

${ }^{m}$ Ministry of Foreign Affairs of the People's Republic of China, "Set aside dispute and pursue joint development". Retrieved on 26 April 2014. http://www.fmprc.gov.cn/eng/ ziliao/3602/3604/t18023.htm

${ }^{\mathrm{n}}$ Ibid.

${ }^{\circ}$ Ibid.

PIbid.

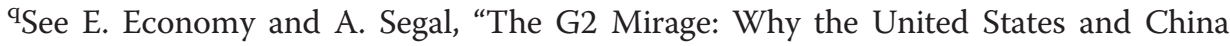
are not ready to upgrade ties", in Foreign Affairs, May/June 2009; CNN, 2 April 2009, "US-China relations in focus at 'G2' summit”. http://edition.cnn.com/2009/WORLD/ europe/04/01/g20.china.us/

rBloomberg, 12 June 2011. "Clinton Chastises China on Internet, African 'New Colonialism”" http://www.bloomberg.com/news/2011-06-11/clinton-chastises-china-on-internetafrican-new-colonialism-.html

${ }^{\text {s} H e g e m o n i c ~ S t a b i l i t y ~ T h e o r y ~ p r o p o s e r s ~ s u c h ~ a s ~ K i n d l e b e r g e r ~(1973), ~ G i l p i n ~(1987) ~ a n d ~}$ Modelski (1987) have argued that the world is a safer place with less conflicts if there is a hegemonic power to dictate order and set the rules.

${ }^{\mathrm{t}}$ Opening speech by Xi Jinping at the Boao Forum. http://www.china.org.cn/business/ Boao_Forum_2013/2013-04/10/content_28501562.htm

Competing interests

The author declares that he has no competing interests.

Received: 7 November 2014 Accepted: 10 November 2014

Published online: 05 February 2015

\section{References}

Alden, C. 2007. China in Africa. London: Zed Books.

Amin, Samir. 1974. Accumulation on a World Scale. Sussex: Harvester Press.

Barro, Robert J. and Lee, Jong-Wha. 2010. A New Data Set of Educational Attainment in the World, 1950-2010. NBER Working Paper No. w15902. Available at SSRN: http://ssrn.com/abstract=1591325

Bell, Daniel A, and Thaddeus Metz. 2011. Confucianism and Ubuntu: reflections on a dialogue between Chinese and African Traditions. Journal of Chinese Philosophy 38(supp): 78-95.

Brautigam, Deborah. 2009. Dragon's Gift: The Real Story of China in Africa. Oxford: Oxford University Press.

Burke, Roland. 2010. Afro-Asian alignment: Charles Malik and the Cold War at Bandung. In Bandung 1955: Little History, ed. Derek McDougall and Antonia Finnane. Victoria: Monash University Press.

Cardoso, Fernando H, and Enzo Faletto. 1979. Dependency and Development in Latin America, trans., Marjory Urquidi. USA: University of California Press.

Cheng, Chung-Ying. 2011a. New Confucianism as a philosophy of humanity and governance. Journal of Chinese Philosophy 38(supp): 1-2. 
Cheng, Chung-Ying. 201 1b. A transformative conception of Confucian ethics: the Yijing, utility, and rights. Journal of Chinese Philosophy 38(supp): 7-28.

Davies, P. 2007. China and the end of poverty in Africa - towards mutual benefit? Report for the European Network on Debt and Development.

Dos Santos, Theotonio. 1971. The Structure of Dependence. In Readings in US Imperialism, ed. KT Fann and Hodges Donald Clark. Boston: Porter Sargent.

Emmanuel, Arghiri. 1972. Unequal Exchange. London: New Left Books.

Escobar, Arturo. 1995. Encountering Development: The Making and Unmaking of the Third World. New Jersey: Princeton University Press.

Finnane, Antonia. 2010. Bandung as History. In Bandung 1955: Little History, ed. Derek McDougall and Antonia Finnane. Victoria: Monash University Press.

Frank, Andre G. 1967. Capitalism and Underdevelopment in Latin America. New York: Monthly Review Press.

Frank, Andre G. 1972. The Development of Underdevelopment. In Dependency and Underdevelopment, ed. JD Cockcroft, AG Frank, and D Johnson. New York: Anchor Books.

Friedman, Milton. 1962. Capitalism and Freedom. Chicago: Chicago University Press (Reprinted 2002).

Fukuyama, Francis. 1992. The End of History and the Last Man. New York: Avon Books.

Galtung, J. 1980. The True Worlds: A Transnational Perspective. New York: The Free Press.

Gilpin, Robert. 1987. The Political Economy of International Relations. Princeton: Princeton University Press.

Gong, Dehong, Qiufa Li, and Minzheng Gao. 1998. Deng Xiaoping Waijiao Zhanlue Sixiang Yanjiu. Beijing: Lantian Chubanshe.

Huntington, Samuel P. 1997. The Clash of Civilizations and the Remaking of World Order. London: Simon and Schuster.

Information of the State Council, the People's Republic of China. (2011). China's Foreign Aid. Available online: http://news. xinhuanet.com/english2010/china/2011-04/21/c_13839683.htm

Johnston, Alastair I. 1995. Cultural Realism: Strategic Culture and Grand Strategy in Chinese History. New Jersey: Princeton University Press.

Kindleberger, C. 1973. The World in Depression, 1929-1939. Los Angeles: University of California Press.

Larrain, Jorge. 1989. Theories of Development: Capitalism, Colonialism and Dependency. Cambridge: Polity Press.

Lauridsen, Kirsten R. 1988. Some Observations on Modern Chinese Confucianism. In Chinese Intellectual Life Post-Mao: Education, Ideology, Literature, and the Arts, ed. Birthe Arendrup. Copenhagen: Center for East and Southeast Asian Studies, Museum Tusculanum Press - University of Copenhagen.

Lenin, Vladimir. 1916. Imperialism, the Highest Stage of Capitalism. Moscow: Progress Publishers (Reprinted 1982, 18 ${ }^{\text {th }}$ printing).

Li, Anshan. 2011. Cultural Heritage and China's Africa Policy. In China and the European Union in Africa, ed. Jing Men and Benjamin Bartons. Surrey: Ashgate Publishing Limited.

Mackie, Jamie. 2005. Bandung 1955: Non-Alignment and Afro-Asian Solidarity. Singapore: Editions Didier Millet.

Modelski, George. 1987. Long Cycles in World Politics. Seattle: University of Washington Press.

Ng, On-cho, and Kai-wing Chow. 1999. Introduction: Fluidity of the Confucian Canon and Discursive Strategies. In Imagining Boundaries: Changing Confucian Doctrines, Texts, and Hermeneutics, ed. Kai-wing Chow, On-cho Ng, and John Henderson. Albany: State University of New York Press.

Nye, Joseph. 2004. Soft Power: The Means to Success in World Politics. New York: Public Affairs.

Prebisch, Raul. 1959. Commercial policy in the underdeveloped countries. American Economic Review 49(2): $251-273$. Papers and Proceedings of the Seventy-first Annual Meeting of the American Economic Association.

Qin, Y. 2010. Why is there no Chinese international relations theories? In Non-Western International Relations Theory: Perspectives on and Beyond Asia, ed. A Acharya and B Buzan. Oxon: Routledge.

Ramos, Joshua C. 2004. The Beijing Consensus. London: The Foreign Policy Centre.

Rose, Jonathan. 2004. The rule of law in the western world: an overview. Journal of Social Philosophy 35(4): 457-470.

Roy, Denny. 1998. China's Foreign Policy. New York: Rowman and Littlefield.

Sautman, B. (2007). Friends and Interests: China's Distinctive Links with Africa. African Studies Review, 50(3).

Schmidt, Sebastian. 2011. To Order the Minds of Scholars: The Discourse of the Peace of Westphalia in International Relations Literature. International Studies Quarterly 55: 601-623.

Shen, Simon. 2010. Multidimentional Diplomacy as a Global Phenomenon. In Multidimensional Diplomacy of Contemporary China, ed. Simon Shen and Jean-Marc Blanchard. Maryland: Lexington Books.

Sole-Farras, Jesus. 2014. New Confucianism in Twenty-First Century China: The Construction of a Discourse. New York: Routledge.

Strange, Susan. 1997. Casino Capitalism. Manchester: Manchester University Press.

Taylor, I. 2006. China's oil diplomacy in Africa. International Affairs 82(5): 937-959.

Tu, Wei-ming. 1994. Introduction: Cultural Perspectives. In China in Transformation, ed. Tu Wei-ming. London: Harvard University Press.

Wallerstein, Immanuel. 1974. Dependence in an interdependent world: the limited possibilities of transformation within the capitalist world economy. African Studies Review 17(April): 1-26.

Wang, Yuan-kang. 2011. Harmony and War: Confucian culture and Chinese power politics. New York: Columbia University Press. Wong, Pak Nung, and Wai Kay Ricky Yue. 2014. US-China containment and counter-containment in Southeast Asia: the "Battle" for Myanmar (Burma). Afr Asian Stud 13: 33-58.

Yan, Xuetong. 2011. In Ancient Chinese Thought, Modern Chinese Power, ed. Daniel Bell and Sun Zhe. New Jersey: Princeton University Press.

Yue, Ricky. 2014. Sino-Myanmar relations: is Pauk-Phaw pragmatic or rhetoric? Journal of Comparative Asian Development 13(2):264-289.

Zhang, Dainian. 1980-81. On the critical inheritance of philosophical thought. Chinese Stud Philos 12(2): 60-69. 